\title{
Synthesis, Crystal and Molecular Structure of Novel Adamantyl Derivatives of $N$-Aryl Substituted 3-Hydroxy-2-methylpyridine-4-ones
}

\author{
Vesna Petrović Peroković, ${ }^{*}$ Biserka Prugovečki, ${ }^{*}$ and Željka Car \\ Department of Chemistry, Faculty of Science, University of Zagreb, Horvatovac 102a, HR-10000 Zagreb, Croatia
}

RECEIVED JULY 24, 2013; REVISED OCTOBER 11, 2013; ACCEPTED OCTOBER 28, 2013

\begin{abstract}
Two novel potentially bioactive compounds, esters 2-methyl-1-phenylpyridine-4-one-3-yl adamantan-1-ylethanoate (1) and 1-(p-methoxyphenyl)-2-methylpyridine-4-one-3-yl adamantan-1ylethanoate (2), were synthesized by esterification of adamantan-1-ylacetic acid with appropriate $N$-aryl substituted 3-hydroxypyridine-4-one derivatives. Both compounds are fully characterized using standard spectroscopic methods. Crystal and molecular structures of $\mathbf{1}$ and $\mathbf{2}$ were determined by the single crystal X-ray diffraction method. The crystal packing of both $\mathbf{1}$ and $\mathbf{2}$ shows separation of the hydrophobic and hydrophilic regions. The crystal structure of $\mathbf{1}$ is characterized by the two-dimensional hydrogen bonding layers parallel to (001). The crystal packing of $\mathbf{2}$ is characterized by hydrogen-bonded chains extended in the direction [010].(doi: 10.5562/cca2339)
\end{abstract}

Keywords: adamantan-1-ylacetic acid, 3-hydroxypyridine-4-ones, single crystal X-ray diffraction, Steglich esterification

\section{INTRODUCTION}

3-Hydroxypyridine-4-ones (3,4-HPOs) are a family of heterocyclic compounds with nitrogen atom in the ring and hydroxyl and keto groups at positions 3 and 4, respectively (Figure 1). The presence of the latter two functionalities allows them to exhibit their excellent chelating properties especially towards M(II) / M(III) metal ions. ${ }^{1-5}$ In therapeutic applications 3,4-HPOs are primarily used as potential sequesters of metal ions in various diseases that can cause metal overload ${ }^{6,7}$ as well as in such conditions that are elicited by metal poisoning. ${ }^{8}$ Furthermore, it has been shown that these ligands present their highest affinity for metal ions under physiological conditions in which they are quite stable, nontoxic and even resistant to enzyme-catalyzed cleavage.

Variation of substituents at positions 1,2,5 and even at position 3 can strongly influence their biological activity. For example, several 3,4-HPOs glycosylated at position 3 have shown great promise for developing multifunctional treatment for Alzheimer's disease. ${ }^{8-11}$ Incorporation of an adequate substituent at a position responsible for pyridine-4-ones chelating ability, in order to increase their solubility and improve pharmacokinetics, can temporarily mask the metal binding site and make these compounds useful and effective prodrugs. $^{9-12}$<smiles>[R]c1c(O)c(=O)ccn1[R]</smiles>

Figure 1. General structure of 3,4-HPO derivatives.

Adamantyl based compounds are used clinically primarily for the treatment of neurological conditions, as antiviral and antitumor agents and potential drugs against type 2 diabetes. ${ }^{13,14}$ In almost all cases compounds that bear the bulky adamantyl group tend to be more lipophilic than their des-adamantyl analogues. Furthermore, this group can modulate therapeutic activity of many experimental drugs and prodrugs by varying their mechanism of action. ${ }^{13}$ These are certaintly good enough reasons for its incorporation in any potential or already biologically active compound.

Given the fact that the structure and function are closely related one can only benefit from the obtained $\mathrm{X}$-ray structure data of potential drugs or prodrugs. The

\footnotetext{
* Authors to whom correspondence should be addressed. (E-mail: vpetrovi@chem.pmf.hr; biserka.prugovecki@chem.pmf.hr)
} 
detailed structure of such compounds can provide extremely useful information that can be subsequently used in elucidation of their mechanism of action. According to the Cambridge Structural Database, CSDB, ${ }^{15}$ a search using the ConQuest Version 1.15 , gave only 22 structures containing the adamantan-1-ylacetyl unit yet no structures which contain both adamantan-1-ylacetyl and 3,4-HPO units.

We have prepared two adamantyl modified 3,4HPOs which are currently used in our ongoing biological study on similar 3,4-HPO derivatives. Preliminary tests have shown that these compounds possess a biological potential. ${ }^{16}$ Pyridinone esters of adamantan-1ylacetic acid were prepared in Steglich esterification conditions. ${ }^{17}$ Crystal and molecular structures of both products were determined by the single crystal X-ray diffraction method.

\section{EXPERIMENTAL}

\section{Synthesis of Adamantan-1-ylacetic Acid Pyridinone Esters}

\section{Materials and Methods}

The chemical reagents used in syntheses were obtained from Fluka or Aldrich Corp. All solvents were purified using standard procedures. Column chromatography (solvents and proportions are given in the text) of products were performed on Merck silica gel 60 (size 70230 mesh ASTM) and thin layer chromatography monitoring (TLC) on Fluka silica gel (60 F 254) plates $(0.25$ $\mathrm{mm})$. Visualization was effected by the use of UV light at $254 \mathrm{~nm}$. Melting points were determined in open capillaries using Büchi B-540 melting point apparatus and are uncorrected. IR spectra were recorded using Perkin Elmer FT-IR Spectrometer Spectrum Two. ${ }^{1} \mathrm{H}$ and ${ }^{13} \mathrm{C}$ NMR spectra were recorded with Bruker Avance spectrometer at room temperature at 300.130 $\mathrm{MHz}$ and $75.468 \mathrm{MHz}$, respectively. Chemical shifts are given in ppm downfield from TMS as internal standard. Electrospray ionization mass spectrometry (ESI-MS) was performed using Agilent 6410 MS instrument. $\mathrm{CHN}$ elemental analyses were carried out by the Analytical Service Laboratory of the Ruđer Bošković Institute.

\section{General Procedure}

An appropriate pyridinone derivative $(0.5 \mathrm{mmol})$ was added to a solution of adamantan-1-ylacetic acid (95 mg, $0.5 \mathrm{mmol})$ in dry $\mathrm{CH}_{2} \mathrm{Cl}_{2}(3 \mathrm{~mL}), \mathrm{N}, \mathrm{N}$-dimethylaminopyridine (DMAP; $6 \mathrm{mg}, 0.05 \mathrm{mmol})$. The mixture was cooled down to $0{ }^{\circ} \mathrm{C}$ and 1-ethyl-3-(3-dimethyaminopropyl)carbodiimide hydrochloride (EDC $\cdot \mathrm{HCl} ; 105 \mathrm{mg}, 0.55$ mmol) was added next. The solution was stirred for 30 min at $0{ }^{\circ} \mathrm{C}$ and subsequently $24 \mathrm{~h}$ at room temperature. The reaction was monitored by TLC (ethyl acetate / methanol 5:2). Dichloromethane was added and the or- ganic layer was washed twice with $0.5 \mathrm{M} \mathrm{HCl}$, then with saturated aqueous $\mathrm{NaHCO}_{3}$ solution and finally dried over $\mathrm{MgSO}_{4}$. After filtration, the organic extract was concentrated in vacuo. The residue was purified by column chromatography on silica gel (ethyl acetate / methanol 5:2) giving the corresponding ester, 1 or $\mathbf{2}$.

2-Methyl-1-phenylpyridine-4-one-3-yl adamantan-1ylethanoate (1): White crystals (125 mg, $67 \%) ; R_{\mathrm{f}}=0.49$ (ethyl acetate / methanol 5:2); m.p. $184.5-185.8{ }^{\circ} \mathrm{C}$ (decomp). IR (KBr) $v_{\max } / \mathrm{cm}^{-1}: 3044,3005$ (C-H arom.), $2901\left(\mathrm{C}-\mathrm{H}_{\mathrm{s}}\right), 2847\left(\mathrm{C}-\mathrm{H}_{\mathrm{as}}\right), 1748(\mathrm{C}=\mathrm{O}$, ester $), 1645$ $(\mathrm{C}=\mathrm{O}$, ketone $), 1497 \quad\left(\mathrm{C}=\mathrm{C}_{\text {arom. }}\right), 1286(\mathrm{C}-\mathrm{N}), 1160$ (C-O, ester). ${ }^{1} \mathrm{H}$ NMR (DMSO- $\left.d_{6}\right) \delta$ (ppm): 1.65 (br s, 6H, $3 \mathrm{H} \gamma-\mathrm{Ad}), 1.72$ (m, 6H, $3 \mathrm{H \alpha}-\mathrm{Ad}), 1.91$ (s, 3H, $\mathrm{CH}_{3}$ ), 1.94 (s, 3H, $3 \mathrm{H} \beta-\mathrm{Ad}), 2.30$ (s, 2H, $\left.\mathrm{CH}_{2}\right), 6.24$ (d, 1H, J= $7.6 \mathrm{~Hz}, \mathrm{H}-5), 7.48-7.51$ (m, 2H, H-Ar), 7.54-7.60 (m, $3 \mathrm{H}, \mathrm{H}-\mathrm{Ar}), 7.69$ (d, $1 \mathrm{H}, J=7.5 \mathrm{~Hz}, \mathrm{H}-6) .{ }^{13} \mathrm{C} \mathrm{NMR}$ (DMSO- $\left.d_{6}\right) \delta$ (ppm): $14.20\left(\mathrm{CH}_{3}\right), 27.92$ (C $\left.\beta-\mathrm{Ad}\right), 32.38$ (C-Ad), 36.13 (C $\gamma$-Ad), 41.40 (C $\alpha-A d), 47.51\left(\mathrm{CH}_{2}\right)$, 115.39 (C-5), 127.04 (2 CH-Ar), 129.31 (CH-Ar), 129.75 (2 CH-Ar), 139.13 (C-3), 140.15 (C-2), 140.71 (C-6), $141.03(\mathrm{C}-\mathrm{N}), 167.79(\mathrm{C}=\mathrm{O}$, ester $), 169,56(\mathrm{C}=\mathrm{O})$. ESIMS: $m / z[\mathrm{M}+\mathrm{H}]^{+}$378.3. Anal. Calcd. mass fraction of elements, $w / \%$, for $\mathrm{C}_{24} \mathrm{H}_{27} \mathrm{NO}_{3}\left(M_{\mathrm{r}}=377.48\right)$ are: $\mathrm{C}$ 76.36, H 7.21, N 3.71, found: C 76.26, H 7.27, N 3.75. 1-(p-Metoxyphenyl)-2-methylpyridine-4-one-3-yl adamantan-1-ylethanoate (2): White crystals $(61 \mathrm{mg}$, $59 \%$ ); $R_{\mathrm{f}}=0.6$ (ethyl acetate / methanol 5:2); m.p. 196.6-197.7 ${ }^{\circ} \mathrm{C}$. IR (KBr) $v_{\max } / \mathrm{cm}^{-1}: 3066,3049$ $\left(\mathrm{C}-\mathrm{H}_{\text {arom. }}\right), 2907\left(\mathrm{C}-\mathrm{H}_{\mathrm{s}}\right), 2845\left(\mathrm{C}-\mathrm{H}_{\mathrm{as}}\right), 1752(\mathrm{C}=\mathrm{O}$, ester $), 1638$ ( $\mathrm{C}=\mathrm{O}$, ketone $), 1511\left(\mathrm{C}=\mathrm{C}_{\text {arom. }}\right), 1287$ $(\mathrm{C}-\mathrm{N}), 1243(\mathrm{C}-\mathrm{O}-\mathrm{C}$, ether $), 1154(\mathrm{C}-\mathrm{O}$, ester $) .{ }^{1} \mathrm{H}$ NMR (DMSO- $\left.d_{6}\right) \delta$ (ppm): 1.65 (s, 6H, $3 \mathrm{H} \gamma$-Ad), 1.72 (s, 6H, $3 \mathrm{H \alpha}$-Ad), 1.90 (s, 3H, $\mathrm{CH}_{3}$ ), 1.95 (s, 3H, $3 \mathrm{H} \beta$ $\mathrm{Ad}), 2.29$ (s, 2H, $\left.\mathrm{CH}_{2}\right), 3.83\left(\mathrm{~s}, 3 \mathrm{H}, \mathrm{OCH}_{3}\right), 6.21(\mathrm{~d}, 1 \mathrm{H}$, $J=7.6 \mathrm{~Hz}, \mathrm{H}-5), 7.09$ (d, 2H, $J=8.9 \mathrm{~Hz}, \mathrm{H}-\mathrm{Ar}), 7.4$ (d, $2 \mathrm{H}, J=8.8 \mathrm{~Hz}, \mathrm{H}-\mathrm{Ar}), 7.63$ (d, 1H, $J=7.6 \mathrm{~Hz}, \mathrm{H}-6)$. ${ }^{13} \mathrm{C}$ NMR (DMSO- $\left.d_{6}\right) \delta(\mathrm{ppm}): 14.10\left(\mathrm{CH}_{3}\right), 27.90(\mathrm{C} \beta-$ Ad), 32.32 (C-Ad), 36.11 (C $\gamma$-Ad), 41.38 (C $\alpha-A d)$, $47.48\left(\mathrm{CH}_{2}\right), 55.43\left(\mathrm{OCH}_{3}\right), 114.65$ (2 CH-Ar), 115.24 (C-5), 128.19 (2 CH-Ar), $133.89(\mathrm{C}-\mathrm{N}), 139.02$ (C-3), 140.53 (C-2), 140.97 (C-6), 159.38 (C-Ar), 167.74 $(\mathrm{C}=\mathrm{O}$, ester $), 169.49(\mathrm{C}=\mathrm{O})$. ESI-MS: $m / z[\mathrm{M}+\mathrm{H}]^{+}$ 408.2. Anal. Calcd. mass fraction of elements, $w / \%$, for $\mathrm{C}_{25} \mathrm{H}_{29} \mathrm{NO}_{4}\left(M_{\mathrm{r}}=407.50\right)$ are: $\mathrm{C} 73.68$, H.7.17, N 3.44, found: C 73.80, H 7.01, N 3.47.

\section{X-ray Crystallography}

The single-crystal X-ray diffraction data of $\mathbf{1}$ and $\mathbf{2}$ were collected by $\omega$-scans on an Oxford Diffraction Xcalibur 3 CCD diffractometer with graphite-monochromated Mo- $K_{\alpha}$ radiation $(\lambda=0.71073 \AA)$. Data reduction was performed using the CrysAlis software package. ${ }^{18}$ Solution, refinement and analysis of the structures were done using the programs integrated in the WinGX system. ${ }^{19}$ 
Table 1. Crystallographic data and structure refinement details for compounds $\mathbf{1}$ and $\mathbf{2}$

\begin{tabular}{|c|c|c|}
\hline & 1 & 2 \\
\hline chemical formula & $\mathrm{C}_{24} \mathrm{H}_{27} \mathrm{NO}_{3}$ & $\mathrm{C}_{25} \mathrm{H}_{29} \mathrm{NO}_{4}$ \\
\hline$M \mathrm{r}$ & 377.47 & 407.49 \\
\hline crystal colour, habit & colourless, plate & colourless, plate \\
\hline crystal dimensions/ $\mathrm{mm}$ & $0.58 \times 0.48 \times 0.08$ & $0.47 \times 0.33 \times 0.15$ \\
\hline crystal system & triclinic & monoclinic \\
\hline space group & $P-1$ & $C 2 / c$ \\
\hline \multicolumn{3}{|l|}{ unit cell parameters } \\
\hline$a / \AA$ & $6.9482(4)$ & $25.669(2)$ \\
\hline$b / \AA$ & $9.1811(5)$ & $9.9870(3)$ \\
\hline$c / \AA$ & $15.6785(8)$ & $22.2003(18)$ \\
\hline$\alpha, \beta, \gamma / \circ$ & $96.302(4), 100.405(4), 957.59(9)$ & $90,132.283(14), 90$ \\
\hline$V / \AA^{3}$ & $957.59(9)$ & $4210.5(11)$ \\
\hline$Z$ & 2 & 8 \\
\hline$D_{\text {cald }} / \mathrm{g} \mathrm{cm}^{-3}$ & 1.309 & 1.286 \\
\hline temperature/ K & $150(2)$ & $295(2)$ \\
\hline wavelength/ $\AA$ & 0.71073 & 0.71073 \\
\hline$\mu / \mathrm{mm}^{-1}$ & 0.086 & 0.086 \\
\hline$F(000)$ & 404 & 1744 \\
\hline number of unique data & 3758 & 3702 \\
\hline number of data $\left[F_{\mathrm{o}} \geq 4 \sigma\left(F_{\mathrm{o}}\right)\right]$ & 2999 & 2842 \\
\hline number of parameters & 361 & 375 \\
\hline$R_{1}{ }^{\mathrm{a}},\left[F_{\mathrm{o}} \geq 4 \sigma\left(F_{\mathrm{o}}\right)\right]$ & 0.038 & 0.050 \\
\hline $\mathrm{w} R_{2}{ }^{\mathrm{b}}$ & 0.104 & 0.127 \\
\hline Goodness of fit on $F^{2}, S^{c}$ & 1.05 & 1.04 \\
\hline$\Delta \rho_{\max }, \Delta \rho_{\min }\left(\mathrm{e} \AA^{-3}\right)$ & $-0.17,0.23$ & $-0.20,0.29$ \\
\hline
\end{tabular}

The structures were solved using SHELXS by direct methods. The refinement procedure was performed by the full-matrix least-squares method based on $F^{2}$ against all reflections using SHELXL. ${ }^{20}$ The non-hydrogen atoms were refined anisotropically. All hydrogen atoms were located in the difference Fourier maps and refined isotropically. Exceptions were hydrogen atoms on atom C18 (methyl group) in $\mathbf{2}$ which were placed in calculated positions and refined using the riding model. Geometrical calculations were done using PLATON. ${ }^{21}$ The structure drawings were prepared using the MERCURY program. ${ }^{22}$ Crystallographic and structure refinement data for $\mathbf{1}$ and $\mathbf{2}$ are summarized in Table 1, whereas the selected bond distances and angles are listed in Table 2.

\section{RESULTS AND DISCUSSION}

\section{Synthesis}

Two different $N$-aryl substituted 3,4-HPOs, namely 3hydroxy-2-methyl-1-phenylpyridine-4-one and 3- hydroxy-1-( $p$-methoxyphenyl)-2-methylpyridine-4-one, were used as an alcohol component in the esterification of adamantan-1-ylacetic acid (Scheme 1). Both pyridinone derivatives were synthesized following the procedure reported by Jakopčić et al. ${ }^{2}$ The incorporation of adamantyl moiety into 3,4-HPO structures was carried out in mild Steglich esterification conditions in the presence of coupling carbodiimide reagent and a catalytic amount of $N, N$-dimethylaminopyridine (DMAP). ${ }^{17}$

As 1-ethyl-3-(3-dimethyaminopropyl)carbodiimide hydrochloride $(\mathrm{EDC} \cdot \mathrm{HCl})$ was used as the coupling reagent, a byproduct, water soluble urea, can be easily removed by extraction and does not contaminate the product. After column chromatography purification, pyridinone esters of adamantan-1-ylacetic acid, 2-methyl-1-phenylpyridine-4-one-3-yl adamantan-1-yl-ethanoate (1) and 1-(p-methoxyphenyl)-2methylpyridine-4-one-3-yl adamantan-1-ylethanoate (2) were isolated in good yields, $67 \%$ and $59 \%$, respectively. Both compounds were characterized using 
Table 2. Selected bond lengths $(\AA)$ and angles $\left(^{\circ}\right)$ for compounds 1 and $\mathbf{2}$

\begin{tabular}{lll}
\hline & $\mathbf{1}$ & $\mathbf{2}$ \\
\hline $\mathrm{O} 1-\mathrm{C} 1$ & $1.2015(17)$ & $1.194(3)$ \\
$\mathrm{O} 2-\mathrm{C} 1$ & $1.3621(17)$ & $1.364(4)$ \\
$\mathrm{O} 1-\mathrm{C} 13$ & $1.4061(16)$ & $1.403(3)$ \\
$\mathrm{O} 3-\mathrm{C} 14$ & $1.2516(15)$ & $1.244(2)$ \\
$\mathrm{N} 1-\mathrm{C} 19$ & $1.4484(16)$ & $1.451(2)$ \\
$\mathrm{C} 1-\mathrm{C} 2$ & $1.5009(19)$ & $1.497(5)$ \\
$\mathrm{C} 2-\mathrm{C} 3$ & $1.5442(18)$ & $1.541(3)$ \\
$\mathrm{C} 3-\mathrm{C} 4$ & $1.540(2)$ & $1.525(3)$ \\
$\mathrm{C} 3-\mathrm{C} 10$ & $1.5384(19)$ & $1.530(6)$ \\
$\mathrm{C} 3-\mathrm{C} 11$ & $1.538(2)$ & $1.522(5)$ \\
$\mathrm{C} 1-\mathrm{O} 2-\mathrm{C} 13$ & $115.92(10)$ & $116.30(17)$ \\
$\mathrm{C} 16-\mathrm{N} 1-\mathrm{C} 17$ & $119.28(11)$ & $119.68(17)$ \\
$\mathrm{C} 16-\mathrm{N} 1-\mathrm{C} 19$ & $118.98(11)$ & $119.4(2)$ \\
$\mathrm{C} 17-\mathrm{N} 1-\mathrm{C} 19$ & $121.63(11)$ & $120.8(2)$ \\
$\mathrm{O} 1-\mathrm{C} 1-\mathrm{O} 2$ & $123.09(12)$ & $122.3(3)$ \\
$\mathrm{O} 1-\mathrm{C} 1-\mathrm{C} 2$ & $125.63(13)$ & $126.0(3)$ \\
$\mathrm{O} 2-\mathrm{C} 1-\mathrm{C} 2$ & $111.28(12)$ & $111.7(2)$ \\
$\mathrm{C} 1-\mathrm{C} 2-\mathrm{C} 3$ & $113.89(11)$ & $114.7(3)$ \\
$\mathrm{C} 4-\mathrm{C} 3-\mathrm{C} 10$ & $108.64(11)$ & $109.6(3)$ \\
$\mathrm{C} 4-\mathrm{C} 3-\mathrm{C} 11$ & $108.40(11)$ & $107.3(3)$ \\
$\mathrm{C} 21-\mathrm{C} 22-\mathrm{C} 23$ & $119.78(14)$ & $120.25(19)$ \\
\hline
\end{tabular}

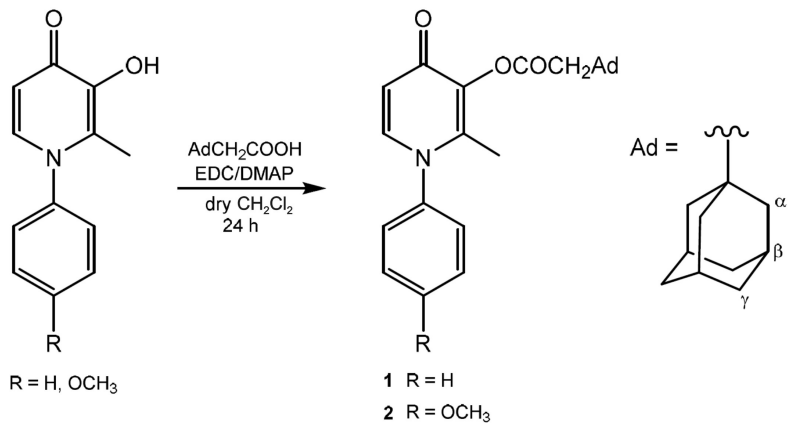

Scheme 1. Synthesis of adamantyl derivatives of 3,4-HPOs.

\section{X-ray Crystallography}

The molecular geometry, as determined by X-ray analysis, and the atom labelling scheme of $\mathbf{1}$ and $\mathbf{2}$ are shown in Figure 2. Differences in the molecular structure of the $\mathbf{1}$ and $\mathbf{2}$ are revealed by their overlay (Figure 3), the greatest being at the methoxy group in $\mathbf{2}$, and by dihedral angles between the pyridinone and phenyl rings. Analysis of the bond lengths revealed only small or insignificant differences in the molecular structure of $\mathbf{1}$ and $\mathbf{2}$ (Table 2).

The adamantane unit in $\mathbf{1}$ and $\mathbf{2}$ consists of four cyclohexanes fused with each other, all approaching the ideal chair conformations. The values of the bond lengths and angles in the adamantane unit are similar to those found in other related compounds. ${ }^{23-25}$ The sixmembered pyridinone and phenyl rings in both $\mathbf{1}$ and $\mathbf{2}$

standard spectroscopic methods, electrospray io zation mass spectrometry and X-ray structural analysis.

a)

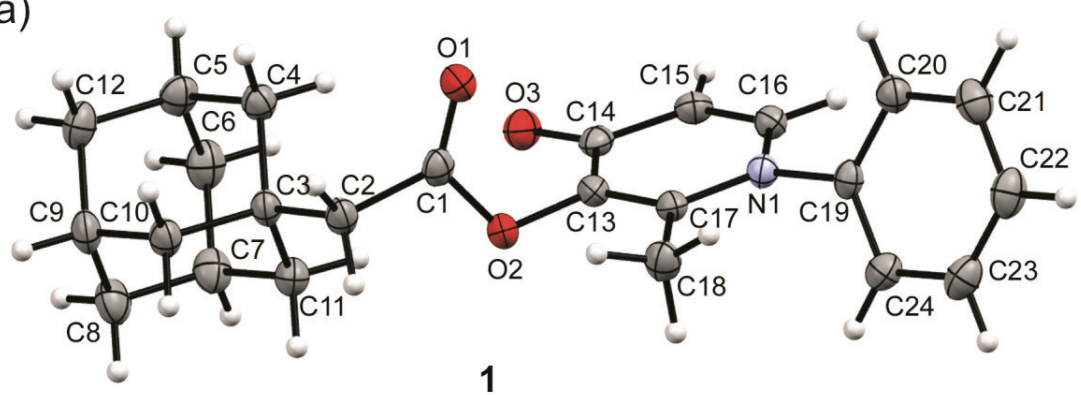

1

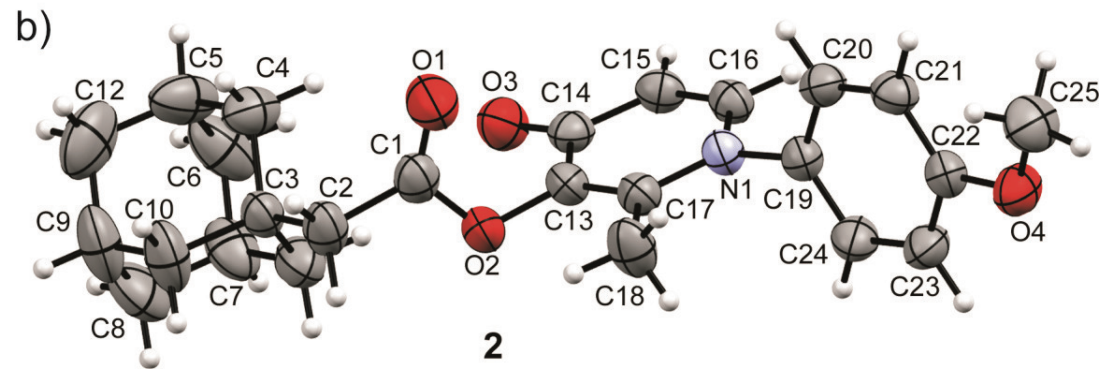

Figure 2. a) The ORTEP drawing of 1. b) The ORTEP drawing of 2. Ellipsoids are shown at the $50 \%$ probability and hydrogen atoms are shown as spheres of arbitrary radii. 
Table 3. Geometry of intermolecular hydrogen bonds $\left(\AA,^{\circ}\right)$ for compounds $\mathbf{1}$ and $\mathbf{2}$

\begin{tabular}{clcccc}
\hline & $\mathrm{D}-\mathrm{H} \cdots \mathrm{A}$ & $\mathrm{D}-\mathrm{H} / \AA$ & $\mathrm{H} \cdots \mathrm{A} / \AA$ & $\mathrm{D} \cdots \mathrm{A} / \AA$ & $\mathrm{D}-\mathrm{H}^{\cdots} \cdot \mathrm{A} /{ }^{\circ}$ \\
\hline $\mathbf{1}$ & $\mathrm{C} 15-\mathrm{H} 15 \cdots \mathrm{O} 1^{\mathrm{i}}$ & $0.983(15)$ & $2.580(15)$ & $3.1877(17)$ & $120.1(11)$ \\
& $\mathrm{C} 16-\mathrm{H} 16 \cdots \mathrm{O} 1^{\mathrm{i}}$ & $0.970(14)$ & $2.659(14)$ & $3.1971(17)$ & $114.4(12)$ \\
& $\mathrm{C} 20-\mathrm{H} 20 \cdots \mathrm{O} 3^{\mathrm{i}}$ & $0.967(15)$ & $2.315(15)$ & $3.2689(17)$ & $168.8(12)$ \\
& $\mathrm{C} 24-\mathrm{H} 24 \cdots \mathrm{O} 3^{\mathrm{ii}}$ & $0.958(15)$ & $2.383(15)$ & $3.2087(17)$ & $144.2(12)$ \\
& $\mathrm{C} 18-\mathrm{H} 18 \mathrm{C} \cdots \mathrm{O} 2$ & $0.964(18)$ & $2.423(17)$ & $2.7931(18)$ & $102.4(12)$ \\
& $\mathrm{C} 15-\mathrm{H} 15 \cdots \mathrm{O} 1^{\text {iii }}$ & $0.95(2)$ & $2.71(3)$ & $3.291(4)$ & $120.2(11)$ \\
& $\mathrm{C} 20-\mathrm{H} 20 \cdots \mathrm{O}{ }^{\text {ii }}$ & $0.96(2)$ & $2.47(2)$ & $3.348(3)$ & $152(3)$ \\
& $\mathrm{C} 21-\mathrm{H} 21 \cdots \mathrm{O} 3^{\text {iv }}$ & $0.96(2)$ & $2.66(2)$ & $3.600(4)$ & $168(2)$ \\
\hline
\end{tabular}

${ }^{\mathrm{i}} 2-x, 1-y, 1-z ;{ }^{\mathrm{ii}} 1-x, 1-y, 1-z ;{ }^{\mathrm{iii}} 2-x, 1-y,-z ;{ }^{\mathrm{iv}} x,-1+y, z$.

are planar with the dihedral angles between the two planes $78.39(13)^{\circ}$ and $60.95(7)^{\circ}$, respectively.

In the previously reported structure of 1- $(p-\mathrm{me}-$ thoxyphenyl)-3-hydroxy-2-methyl-4-pyridinone(Hpap) the pyridinone ring is slightly nonplanar and the phenyl ring is planar. The dihedral angle between the two planes is $73.7^{\circ}$, which is quite different than in 2. ${ }^{26}$ The pattern of the bond lengths within the pyridinone and phenyl rings in $\mathbf{2}$ is similar to that observed in the Hpap molecule. Exception is a longer $\mathrm{O} 2-\mathrm{C} 13$ bond $(1.403(3) \AA$ in 2 and 1.357(2) $\AA$ in Hрap).

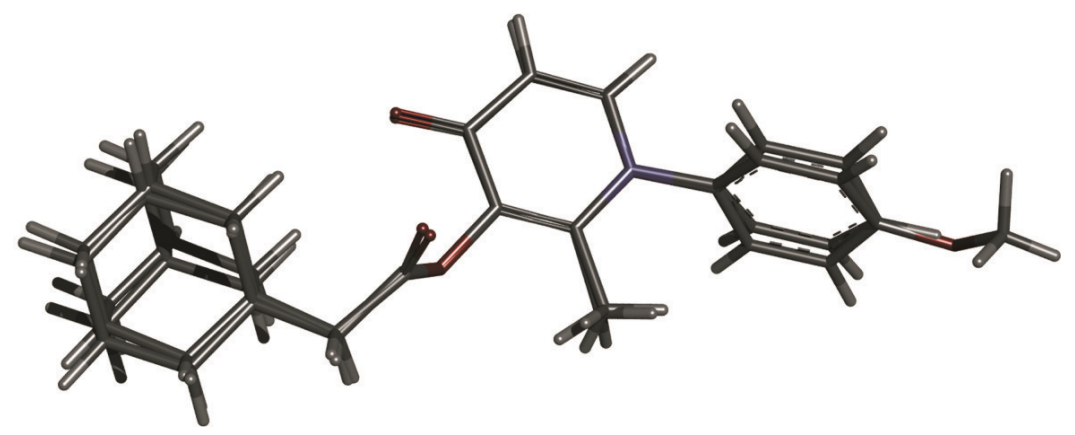

Figure 3. Superposition of the molecules of $\mathbf{1}$ and $\mathbf{2}$.

a)

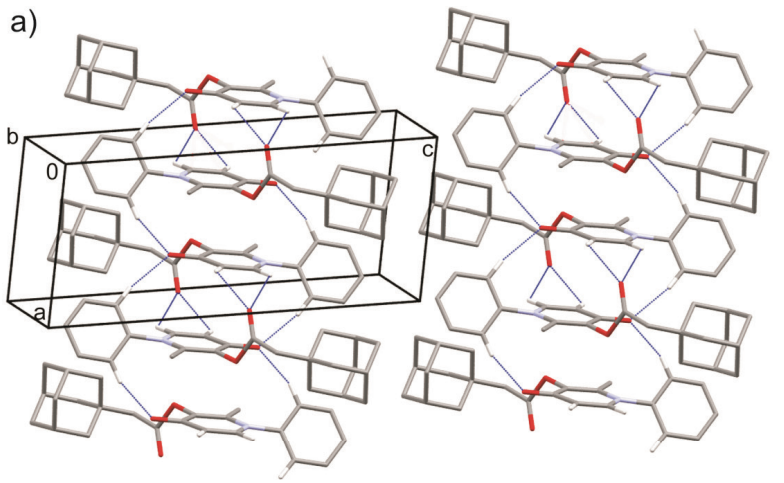

b)

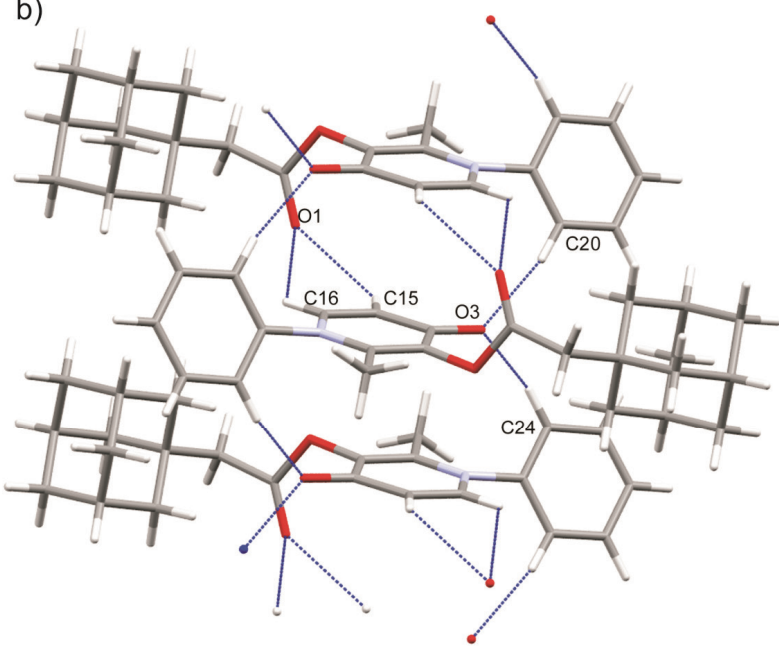

Figure 4. The crystal packing of 1: a) Partial structural motif of the two-dimensional hydrogen bonding network, layers parallel to (001) (hydrogen atoms that are not participating in intermolecular hydrogen bonds including the intramolecular $\mathrm{C} 18-\mathrm{H} 18 \mathrm{C} \cdots \mathrm{O} 2$ hydrogen bond are omitted for clarity). Hydrogen-bonds are shown by blue dotted lines. b) Weak $\mathrm{C}-\mathrm{H} \cdots \mathrm{O}$ hydrogen bonds

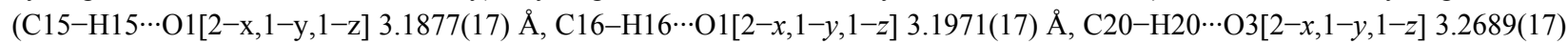
$\AA$ and $\mathrm{C} 24-\mathrm{H} 24 \cdots \mathrm{O} 3[1-x, 1-y, 1-z] 3.2087(17) \AA$ ). Hydrogen-bonds are shown by blue dotted lines. 
a)

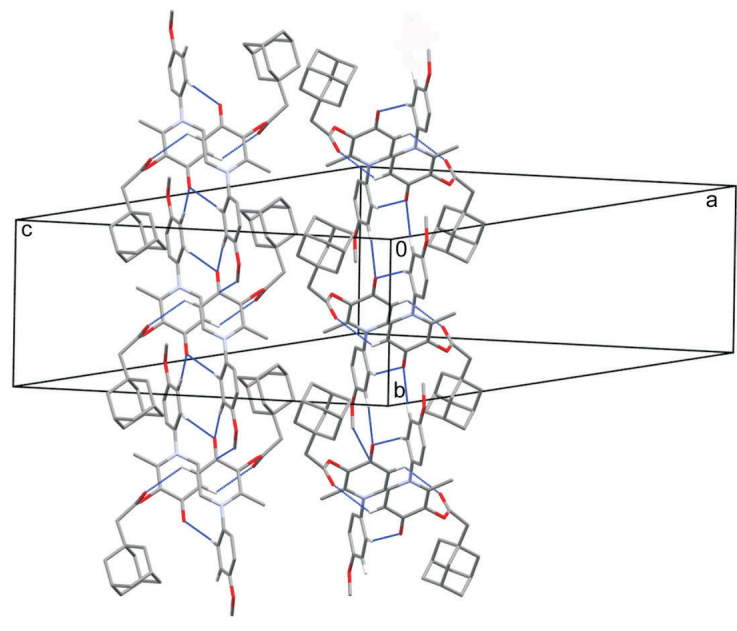

b)

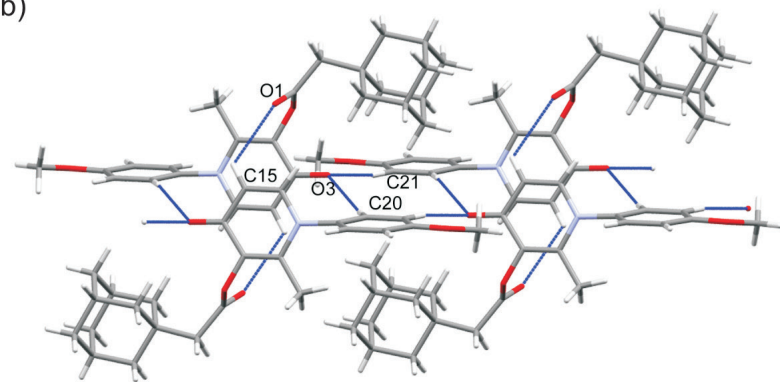

Figure 5. Packing in the unit cell of 2: a) Partial structural motif of the hydrogen bonded chains extended in the direction [010] (hydrogen atoms not participating in hydrogen bonds are omitted for clarity). Hydrogen-bonds are shown by blue dotted lines. b) Weak $\mathrm{C}-\mathrm{H} \cdots \mathrm{O}$

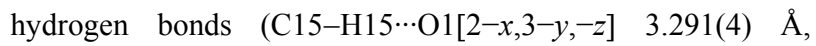
$\mathrm{C} 20-\mathrm{H} 20 \cdots \mathrm{O} 3[2-x, 1-y,-z] \quad 3.348(3) \AA$ and $\mathrm{C} 21-\mathrm{H} 21 \cdots \mathrm{O} 3$ $[x,-1+y, z] 3.600(4) \AA$ ). Hydrogen-bonds are shown by blue dotted lines.

There are no classical hydrogen bonds in the crystal structures of $\mathbf{1}$ and 2, however weak intermolecular $\mathrm{C}-\mathrm{H} \cdots \mathrm{O}$ hydrogen bonds are present (Table 3 ). The $\mathrm{X}$ ray structure of $\mathbf{1}$ also reveals an intramolecular hydrogen bond $\mathrm{C} 18-\mathrm{H} 18 \mathrm{C} \cdots \mathrm{O} 2$ (Table 3). The crystal packing of both 1 and 2 shows separation of the hydrophobic and hydrophilic regions. In 1 the hydrogen bonds connect the molecules into layers parallel to (001) (Figure 4a). Hydrogen bonds in $\mathbf{1}$ involve double acceptors, the ester carbonyl oxygen atom (O1) and the keto group oxygen atom from the pyridinone moiety $(\mathrm{O} 3) . \mathrm{C}$ and $\mathrm{H}$ atoms from the phenyl (C20 and $\mathrm{C} 24)$ and from the pyridinone ring ( $\mathrm{C} 15$ and $\mathrm{C} 16)$ serve as hydrogen bond donors (Figure 4b). The crystal packing of $\mathbf{2}$ is characterized by hydrogen-bonded chains extended in the direction [010] (Figure 5a). Hydrogen bonds in $\mathbf{2}$ involve a double acceptor function of the keto group oxygen atom $\mathrm{O} 3$ and donors from the aromatic $\mathrm{C} 20-\mathrm{H} 20$ and $\mathrm{C} 21-\mathrm{H} 21$ atoms. Additionaly, the ester carbonyl oxygen atom (O1) serves as the hydrogen bond acceptor and $\mathrm{C} 15-\mathrm{H} 15$ from the pyridinone unit as the hydrogen bond donor (Figure $5 b$ ).

\section{CONCLUSION}

Two pyridinone esters of adamantan-1-ylacetic acid were prepared in satisfactory yields. The procedure involved mild Steglich esterification in which two $\mathrm{N}$ aryl substituted 3,4-HPO derivatives were used as the alcohol part. The final pyridinones $\mathbf{1}$ and $\mathbf{2}$ bearing the adamantyl moiety were fully characterized by standard spectroscopic methods and also by the X-ray structural analysis. The crystal packing of both $\mathbf{1}$ and $\mathbf{2}$ shows separation of the hydrophobic and hydrophilic regions. There are no classical hydrogen bonds in the crystal structures of $\mathbf{1}$ and 2, however weak intermolecular $\mathrm{C}-\mathrm{H} \cdots \mathrm{O}$ hydrogen bonds are present. The crystal packing of $\mathbf{1}$ is characterized by the hydrogen bonds connecting molecules into layers parallel to (001) while the crystal packing of $\mathbf{2}$ is characterized by hydrogenbonded chains extended in the direction [010].

Supplementary Materials. - CCDC 950307 and 950308 contain the supplementary crystallographic data for this paper. These data can be obtained free of charge via www.ccdc.cam.ac.uk/data request/cif, or by e-mailing to data request@ccdc.cam.ac.uk, or by contacting The Cambridge Crystallographic Centre, 12, Union Road, Cambridge CB2 1EZ, UK; fax: +44 1223336033.

Acknowledgements. We wish to thank the Ministry of Science, Education and Sports of the Republic of Croatia for support of this work (projects 119-1191344-3121 and 119-11930791084).

\section{REFERENCES}

1. A. Gojmerac Ivšić, V. Tomišić, Ž. Car, B. Prugovečki, and S. Tomić, J. Mol. Struct. 990 (2011) 237-243.

2. K. Jakopčić, B. Tamhina, F. Zorko, and M. J. Herak, J. Inorg Nucl. Chem. 39 (1977) 1201-1203.

3. B. Tamhina, K. Jakopčić, F. Zorko, and M. J. Herak, J. Inorg. Nucl. Chem. 36 (1974) 1855-1857.

4. M. Tsuchiya, K. Kohata, T. Odashima, and H. Ishii, Analyt. Sci. 11 (1995) 343-347.

5. R. Lang, K. Polborn, T. Severin, and K. Severin, Inorg. Chim. Acta 294 (1999) 62-67.

6. L. Saghaie and R. C. Hider, Res. Pharm. Sci. 3 (2008) 21-30.

7. L. Saghaie, M. Mirmohammad Sadeghi, and A. Nikazama, Res. Pharm. Sci. 1 (2006) 40-48.

8. M. A. Santos, S. M. Marques, and S. Chaves, Coord. Chem. Rev. 256 (2012) 240-259.

9. L. E. Scott, B. D. G. Page, B. O. Patrick, and C. Orvig, Dalton Trans. (2008) 6364-6367.

10. D. E. Green, M. L. Bowen, L. E. Scoot, T. Storr, M. Merkel, K. Böhmerle, K. H. Thompson, B. O. Patrick, H. J. Schugar, and C. Orvig, Dalton Trans. 39 (2010) 1604-1615. 
11. L. E. Scott, M. Telpoukhovskaia, C. Rodriguez-Rodriguez, M. Merkel, M. L. Bowen, B. D. G. Page, D. E. Green, T. Storr, F. Thomas, D. D. Allen, P. R. Lockman, B. O. Patrick, M. J. Adam, and C. Orvig, Chem. Sci. 2 (2011) 642-648.

12. H. Schugar, D. E. Green, M. L. Bowen, L. E. Scott, T. Storr, K. Böhmerle, F. Thomas, D. D. Allen, P. R. Lockman, M. Merkel, K. H. Thompson, and C. Orvig, Angew. Chem., Int. Ed. 46 (2007) 1716-1718.

13. J. Liu, D. Obando, V. Liao, T. Lifa, and R. Codd, Eur. J. Med. Chem. 46 (2011) 1949-1963.

14. a) M. A. el-Sherbeny, Arch. Pharm. (Weinheim) 333 (2000) 323 328; b) A. Chimirri, R. Gitto, S. Grasso, A. M. Monforte, and M. Zappala, Farmaco 49 (1994) 649-651; c) J. J. Wang, S. S. Wang, C. F. Lee, M. A. Chung, and Y. T. Chern, Chemotherapy 43 (1997) 182-189; d) J. C. Stoof, J. Booji, B. Drukarch, and E. C. Wolters, Eur. J. Pharmacol. 213 (1992) 439-443; e) R. J. Uitti, A. H. Rajput, J. E. Ahlskog, K. P. Offord, D. R. Schroeder, M. M. Ho, M. Prasad, A. Rajpurt, and P. Basran, Neurology 46 (1996) 1551-1556; f) M. Merello, M. I. Nouzeilles, A. Cammarota, and R. Leiguarda, Clin. Neuropharmacol. 22 (1999) 273-276; g) G. Fytas, P. Marakos, N. Kolocouris, G. B. Foscolos, N. Pouli, A. Vamvakides, S. Ikeda, and E. De Clercq, Farmaco 49 (1994) 641-647; h) J. Vamecq, K. Van Derpoorten, J. H. Poupaert, J. Balzarini, E. De Clercq, and J. P. Stables, Life Sci. 63 (1998) PL267-PL274; i) M. E. Burstein, A. V. Serbin, T. V. Khakhulina, I. V. Alymova, L. L. Stotskaya, O. P. Bogdan, E.
E. Manukchina, V. V. Jdanov, N. K. Sharova, and A. G. Bukrinskaya, Antiviral Res. 41 (1999) 135-144.

15. F. H. Allen, Acta Crystallogr. B58 (2002) 380; The Cambridge Structural Database, ConQuest Version 1.15.

16. V. Petrović Peroković et al., unpublished results.

17. B. Neises and W. Steglich, Agnew. Chem. Int. Ed. Engl. 17 (1978) 522-524.

18. Xcalibur CCD system, CRYSALIS Software system CrysAlisPro, Version 1.171.34.44; Oxford Diffraction Ltd.: Oxfordshire, UK, 2010

19. L. J. Farrugia, J. Appl. Crystallogr. 32 (1999) 837-838.

20. G. M. Sheldrick, Acta Crystallogr. A64 (2008) 112-122.

21. A. L. Spek, J. Appl. Cryst. 36 (2003) 7-13.

22. C. F. Macrae, I. J. Bruno, J. A. Chisholm, P. R. Edgington, P. McCabe, E. Pidcock, L. Rodriguez-Monge, R. Taylor, M. Towler, J. Van der Streek, and P. A. Wood, J. Appl. Crystallogr. 41 (2008) 466-470.

23. M. Matković, J. Veljković, K. Mlinarić-Majerski, K. Molčanov, and B. Kojić-Prodić, J. Mol. Struct. 832 (2007) 191-198.

24. V. Petrović Peroković, R. Ribić, B. Prugovečki, D. MatkovićČalogović, and S. Tomić, Croat. Chem. Acta 85(4) (2012) 419-423.

25. N. Basarić, K. Molčanov, M. Matković, B. Kojić-Prodić, and K. Mlinarić-Majerski, Tetrahedron 63 (2007) 7985-7996.

26. Z. Zhang, S. J. Retting, and C. Orvig, Can. J. Chem. 70 (1992) 763-770. 